\title{
ANALYTICAL MICROBIOLOGY METHODS
}

Chromatography and

Mass Spectrometry 


\title{
ANALYTICAL MICROBIOLOGY METHODS \\ Chromatography and Mass Spectrometry
}

\author{
Edited by \\ Alvin Fox and Stephen L. Morgan \\ University of South Carolina \\ Columbia, South Carolina \\ Lennart Larsson and Göran Odham \\ University of Lund \\ Lund, Sweden
}




\section{Library of Congress Cataloging in Publication Data}

Analytical microbiology methods: chromatography and mass spectrometry / edited by Alvin Fox . . . [ [et al.].

p. $\mathrm{cm}$.

"Based on the proceedings of the First International Symposium on the Interface between Microbiology and Analytical Chemistry, held June 3-7, 1987, at the University of South Carolina, Columbia, South Carolina"-T.p. verso.

Includes bibliographical references.

ISBN 978-1-4899-3566-3

1. Chromatography-Congresses. 2. Mass spectrometry-Congresses. 3. Diagnostic bacteriology - Technique-Congresses. I. Fox, Alvin. II. International Symposium on the Interface between Microbiology and Analytical Chemistry (1st:1987:University of South Carolina)

Based on the proceedings of the First International Symposium on the Interface between Microbiology and Analytical Chemistry, held June 3-7, 1987, at the University of South Carolina, Columbia, South Carolina

(C) Springer Science+Business Media New York 1990

Originally published by Plenum Press, New York in 1990

Softcover reprint of the hardcover 1st edition 1990

\section{All rights reserved}

No part of this book may be reproduced, stored in a retrieval system, or transmitted in any form or by any means, electronic, mechanical, photocopying, microfilming, recording, or otherwise, without written permission from the Publisher 


\section{PREFACE}

The First International Symposium on the Interface between Analytical Chemistry and Microbiology: Applications of Chromatography and Mass Spectrometry was held June 1987 at the University of South Carolina, Columbia, SC, U.S.A. The purpose of the "Interface" meeting was to forge connections between analytical chemists and microbiologists that are using chromatography and mass spectrometry to solve common problems. The goals were admirably fulfilled. Nearly a hundred participants from seven European countries, Japan, and the United States participated in hearing twenty-three plenary talks and thirty-six submitted papers and posters. The papers and discussions displayed the breadth and depth of current research applications and revealed future directions.

This book "Analytical Microbiology Methods: Chromatography and Mass Spectrometry" is loosely based on some of the presentations and discussions at the meeting. Each chapter describes specific methodology and applications in the context of the relevant scientific background. The present book continues the theme of an earlier book, "Gas Chromatography/Mass Spectrometry Applications in Microbiology", edited by G. Odham, L. Larsson, and P-A. Mardh, published by Plenum Press in 1984.

Microbial chemistry has been extremely important in identifying many major structural components of microorganisms (e.g., the teichoic acids, lipopolysaccharides, and peptidoglycans). Structural information has helped provide an understanding of the functional role of many of these molecules in the physiology of the bacterial cell. The uniqueness of many of the monomers present in these macromolecules as well as their natural variability between bacterial species has also provided a framework for chemotaxonomy. The advent of modern analytical chemical methods based on chromatography and mass spectrometry has clarified and expanded on previously known chemical data. often, this information was not obtainable by more traditional approaches.

The advances in analytical microbiology described in this book have the potential to stimulate a revolution of improved methods for automated and rapid identification of microorganisms, characterization of microbial products and constituents, and trace detection of microbial chemicals. We see the beginnings of a new discipline, "Analytical Microbiology", arising at the interface between analytical chemistry and microbiology.

Alvin Fox and Stephen L. Morgan Columbia, SC

Lennart Larsson and Goran Odham Lund, Sweden 
CONTENTS

Chapter 1

Analytical Microbiology: A Perspective . . . . . . . . . . . . . . . . . 1 Alvin Fox, James Gilbart, and Stephen. L. Morgan

Chapter 2

Gas Chromatography and Mass Spectrometry for Analytical Microbiology . . 19 Kimio Ueda, Stephen L. Morgan, and Alvin Fox

Chapter 3

The Chemotaxonomy of Coryneform Organisms . . . . . . . . . . . . . . . 53 Cecil S. Cummins

Chapter 4

The Use of Cellular Fatty Acids for Identification of . . . . . . . . . 59 Microarganisms

C. Wayne Moss

Chapter 5

Profiling and Detection of Bacterial Carbohydrates . . . . . . . . . 71

Alvin Fox, James Gilbart, and Stephen L. Morgan

Chapter 6

Analysis of Bacterial Amino Acids . . . . . . . . . . . . . . . . . . . 89

Alvin Fox, Kimio Ueda, and Stephen L. Morgan

Chapter 7

Headspace Analysis by Gas Chromatography-Mass . . . . . . . . . . . . .101 Spectrometry of Volatile Organic Compounds Associated with Clostridium Cultures

Alain Rimbault

Chapter 8

Identification of Pathogenic Bacteria by Headspace . . . . . . . . . . 125 Gas Chromatography

Horst S. H. Seifert, Sabine Giercke-Sygusch, and Helge Boehnel

Chapter 9

High Performance Chromatographic and Spectroscopic. . . . . . . . . . 137 Analyses of Mycobacterial Waxes and Glycolipids

David E. Minnikin, Gary Dobson, Robert C. Bolton, James H. Parlett, and Anthony I. Mallet 
Chapter 10

Structural Elucidation of Lipopolysaccharides and . . . . . . . . . . . 149 their Lipid A Component: Application of Soft Ionization Mass Spectrometry

Buko Lindner, Ulrich Zahringer, Ernst Th. Rietschel, and Ulrich Seydel

Chapter 11

Structural Determination of Unsaturated Long Chain . . . . . . . . . . 163 Fatty Acids from Mycobacteria by Capillary Gas Chromatography and Collision Activation Dissociation Mass Spectrometry

Jean-Claude Prome, Helene Aure1le, Francois Couderc, Danielle Prome, Arlette Savagnac, and Michel Treilhou

Chapter 12

Pyrolysis GC/MS Profiling of Chemical Markers for . . . . . . . . . . .179 Microorganisms

Stephen L. Morgan, Bruce E. Watt, Kimio Ueda, and Alvin Fox

Chapter 13

Rapid Characterization of Microorganisms by Curie-Point . . . . . . . 201 Pyrolysis in Combination with Short Column Capillary Gas Chromatography and Ion Trap Mass Spectrometry

A. Peter Snyder, William H. McClennen, and Henk L. C. Meuzelaar

Chapter 14

Ultrasensitive Determination of Lipid Biomarkers by . . . . . . . . . .219

Gas Chromatography and Mass Spectrometry in

Clinical and Ecological Microbiology

Lennart Larsson and Goran Odham

Chapter 15

Gas Chromatographic and Mass Spectrometric Techniques . . . . . . . . 239 for the Diagnosis of Disseminated Candidiasis John Roboz

Chapter 16

Use of Lipid Biomarkers in Environmental Samples . . . . . . . . . . . 259 Anders Tunlid and David C. White

Index . . . . . . . . . . . . . . . . . . . . . . . 275 